\title{
Carbon and nitrogen fluxes in sediment inhabited by suspension-feeding (Nereis diversicolor) and non-suspension-feeding $(N$. virens) polychaetes
}

\author{
Bjarne Christensen, Anders Vedel, Erik Kristensen*
}

Institute of Biology, Odense University, SDU, 5230 Odense M, Denmark

\begin{abstract}
The impact of suspension-feeding Nereis diversicolor and non-suspension-feeding $N$ virens on $\mathrm{C}$ and $\mathrm{N}$ dynamics in an organic-poor sediment was investigated in a controlled laboratory study simulating periods of high and low phytoplankton (Rhodomonas sp.) concentration. High phytoplankton concentration resulted in a 30 -fold higher deposition (clearance) of particulate $\mathrm{C}$ and $\mathrm{N}$ to the sediment inhabited by $N$. diversicolor than to $N$, virens and defaunated sediment. Concurrently, $\mathrm{O}_{2}$ consumption and $\mathrm{NH}_{4}{ }^{+}+\mathrm{NO}_{3}{ }^{-}$release were increased by a factor of 3 in sediment with $\mathrm{N}$. diversicolor, but only by a factor of about 1.5 in $N$. virens and defaunated treatments. Steady-state porewater concentrations of $\mathrm{TCO}_{2}$ and $\mathrm{NH}_{4}{ }^{+}$decreased exponentially with increasing ventilation activity of nereids. Ventilation activity was highest for suspension-feeding $N$. diversicolor and lowest for deposit-feeding $N$. virens. About $30 \%$ of the deposited algal $\mathrm{C}$ and $\mathrm{N}$ in the $N$. diversicolor sediment were lost rapidly as excess $\mathrm{CO}_{2}$ or $\mathrm{NH}_{4}^{+}+\mathrm{NO}_{3}^{-}$flux to the water column. Incorporation into $\mathrm{N}$. diversicolor tissues accounted for $2 / 3$ of the retained $C$ and $N$. In the case of $N$. virens, where no net phytoplankton deposition occurred, organic matter removal due to mineralization resulted in a net loss of both sedimentary $\mathrm{C}$ and $\mathrm{N}$. Accordingly, the biology and behaviour of infaunal species are important determinants for sediment biogeochemistry and element cycling in marine areas
\end{abstract}

KEY WORDS: Carbon - Deposit-feeding · Fluxes - Nereis diversicolor - Nereis virens - Nitrogen Sandy sediment Suspension-feeding

\section{INTRODUCTION}

Fluxes across the sediment-water interface and transformation of carbon and nitrogen substances within the sediment are important processes in the biogeochemical element cycling of marine environments. Deposition of organic particles onto coastal sediments is basically controlled by plankton dynamics and hydrography, but the intensity of physical and biological resuspension, infaunal particle mixing and biodeposition are important factors determining net incorporation into sediments (Aller 1982, Wheatcroft et al. 1994. Graf \& Rosenberg 1997).

Settling of organic particles can be accelerated considerably by the activities of suspension-feeding infauna (Meadows et al. 1990, Miller et al. 1992). They meet their nutritional demands by extracting sus-

•Corresponding author. E-mail: ebk@biology.ou.dk pended particles (e.g. phytoplankton) from ventilation currents (Gerritsen et al. 1994, Riisgård \& Larsen 1995), thus enhancing the deposition at the sediment surface directly in the form of biodeposited fecal pellets (Vedel et al. 1994, Graf \& Rosenberg 1997). Deposit-feeding infauna may increase deposition indirectly by creating a stagnant boundary layer between densely packed tubes (Rhoads et al. 1978) or by enhancing passive deposition into feeding pits (Yager et al. 1993). The infauna may also enhance resuspension with subsequent lateral advection by ejection of particles into the overlying water (Bender \& Davis 1984, Rowden \& Jones 1994) or by destabilization of the sediment surface during feeding and tube building (Eckman et al. 1981)

Removal of organic matter from coastal marine sediments is, in addition to resuspension events, mediated largely by aerobic and anaerobic microbial mineralization processes with a significant macrobenthic component (Hansen \& Blackburn 1992, Aller 1994). Burrow- 
dwelling animals are known to stimulate decomposition processes in sediments (Andersen \& Kristensen 1991, Marinelli \& Boudreau 1996). Irrigation and burrowing create steeper solute gradients, enhance fluxes and impart a multidimensional heterogeneity to the sediment matrix in both time and space (Martin \& Banta 1992, Krager \& Woodin 1993, Aller 1994) Infaunal burrows in coastal areas can thus be viewed as microbially dynamic extensions of the sediment surface with oxidized walls and a short distance between aerobic and anaerobic layers (Reichardt 1988, Fenchel 1996).

The widely distributed and closely related marine polychaetes Nereis diversicolor and $N$. virens are known as important bioturbators of shallow coastal sediments (e.g. Kristensen 1988, Hansen \& Kristensen 1997). Although they both live in more or less Ushaped burrows and are often found in coexistence, the former has an affinity for relatively organic-rich sediments whereas the latter prefer more sandy, organic-poor sediments (Miron \& Kristensen 1993). Both are omnivores (detritivores), but $N$. diversicolor also has the ability to live solely as a suspension-feeder (Vedel \& Riisgård 1993, Nielsen et al. 1995). It spins and attaches a mucus net near the entrance of the burrow and pumps water through the net by undulating body movements. The net, containing trapped food particles, is then swallowed and a new cycle is started. Above a certain threshold of phytoplankton concentration in the water column (1 to $\left.3 \mu \mathrm{g} \mathrm{chl} \mathrm{a} \mathrm{l}^{-1}\right) \mathrm{N}$. diversicolor conducts its suspension-feeding cycle repeatedly (Riisgård 1991, Vedel et al. 1994). No such suspensionfeeding has been observed in $N$. virens.

The purpose of this experimental study was to investigate the role of suspension-feeding (Nereis diversicolor) and non-suspension-feeding (Nereis virens) nereid polychaetes for carbon and nitrogen fluxes in a shallow coastal sediment. Controlled laboratory experiments with microcosms inhabited by the 2 nereid species were conducted with and without an excess phytoplankton food source in the overlying water. Based on the downward flux of phytoplankton carbon and nitrogen and upward flux of dissolved inorganic carbon and nitrogen, budgets for the sediment environment were established and the role of polychaete feeding mode was evaluated.

\section{MATERIAIS AND METHODS}

Sediment and worm collection. Sediment and worms were collected in March from the innermost part of the shallow cove Kertinge Nor, Denmark. For a detailed description of the study area consult Risgard et al. (1995). The study site was characterized by non- vegetated sandy sediment inhabited by populations of Nereis diversicolor and $N$. virens at densities of 500 to 1000 ind $\mathrm{m}^{-2}$ (Miron \& Kristensen 1993). Water depth, salinity and temperature were $1 \mathrm{~m}, 18 \%$ and $5^{\circ} \mathrm{C}$, respectively. Sediment, which consisted of well-sorted low-organic sand, was gently sieved through a $1 \mathrm{~mm}$ mesh to remove larger macrafauna and homogenized by hand. Sediment microcosms were established by transferring the homogenized sediment into $25 \mathrm{~cm}$ long and $8 \mathrm{~cm}$ i.d. plexiglass core liners to a depth of $\sim 14 \mathrm{~cm}$. The sediment was then allowed to stabilize in the cores for $8 \mathrm{~d}$. Although the process of sieving and sediment mixing disturbs the original chemical gradients and obstructs any direct extrapolation to in situ conditions (van Duyl et al. 1992), it is preferred here for comparative purposes.

Intact and healthy specimens of Nereis diversicolor and $N$. virens were collected in the sampling area by gentle sieving and were acclimated to the experimental temperature $\left(15^{\circ} \mathrm{C}\right)$ for $1 \mathrm{wk}$.

Experimental set-up. Three nereid worms $(\sim 400 \mathrm{mg}$ wet wt each) were added to each of 12 cores (equivalent to a density of 600 ind. $\mathrm{m}^{-2}$ ), i.e. 6 with Nereis diversicolor and 6 with $N$. virens. An additional 6 cores were used as defaunated controls. The worms were allowed to establish in the sediment for a period of $12 \mathrm{~d}$ under experimental conditions by placing the cores in 2 darkened tanks, each containing $400 \mathrm{l}$ of seawater $\left(18 \%\right.$ and $\left.15^{\circ} \mathrm{C}\right)$. Subsequently, the experiment was initiated by replacing the tank water with $0.2 \mu \mathrm{m}$ filtered, phytoplankton-free seawater. Phytoplankton (Rhodomonas sp.) was added to 1 tank containing half of the cores (AC, AD and AV cores representing control, $N$. diversicolor and $N$. virens treatments, respectively) at a concentration of 10000 cells $\mathrm{ml}^{-1}$, while the other tank with the remaining cores (C, D and $V$ cores representing control, $N$. diversicolor and $N$. virens treatments, respectively) was maintained algal-free. The concentration of phytoplankton in the former tank was kept constant during the entire experiment by daily adjustments. To ensure homogeneous distribution of algae, the water was vigorously aerated and circulated. Each core was supplied with an internal magnetic stirrer rod driven by external rotating magnets ( $-80 \mathrm{rpm})$ to assure continuous exchange of water between core tubes and the surrounding tank.

Clearance measurements. Once every week for a period of $27 \mathrm{~d}$, the clearance of algae from the water phase above the sediment was determined in all core tynes from the tank with phytoplankton. Clearance was measured by elevating the cores above the water surface and supplying theñ with air diffusers to completely stir the water phase without resuspending the sediment surface. and subsequently following algal disappearance in a time series of samplings. A coulter counter (Elzone- 
$80 \mathrm{XY}$ ) was used to determine algal concentrations. For determination of particulate $\mathrm{C}$ and $\mathrm{N}$ content, Rhodomonas sp. cells were concentrated by centrifugation (3000 rpm; $1200 \times \mathrm{g}$ ) of $10 \mathrm{ml}$ samples from a batch culture of known cell concentrations. Carbon and nitrogen content of the pre-weighed and dried $\left(105^{\circ} \mathrm{C}, 24 \mathrm{~h}\right)$ algal material were analyzed on a Carlo Erba CHNanalyzer according to Kristensen \& Andersen (1987).

Flux measurements. Fluxes of $\mathrm{O}_{2}$ and DIN $\left(\mathrm{NO}_{3}{ }^{-}\right.$and $\mathrm{NH}_{4}{ }^{+}$) were measured every third day by sealing the cores with Plexiglas lids. The incubations were terminated before oxygen concentration decreased more than $20 \%$ to ensure a linear change in solute concentrations of the enclosed water volume. Initial and final water samples were GF/C filtered before further handling. Oxygen samples were measured immediately by the standard Winkler technique. Samples for DIN were frozen and analyzed as soon as possible. $\mathrm{NH}_{4}{ }^{+}$ was determined manually using the salicylate method according to Bower \& Holm-Hansen (1980). $\mathrm{NO}_{3}^{-}$ $\left(\mathrm{NO}_{2}{ }^{-}\right.$was insignificant and is included in $\left.\mathrm{NO}_{3}{ }^{-}\right)$was analyzed by the standard autoanalyzer method of Armstrong et al. (1967).

Core sectioning. At the end of the experiment all cores were sectioned into the following depth intervals: 0 to $0.5,0.5$ to 1,1 to 2,2 to 3,3 to 4,4 to 6,6 to 8 and 8 to $10 \mathrm{~cm}$. The sediment fractions were analyzed for porewater and solid phase characteristics. Porewater samples for $\mathrm{TCO}_{2}$ and DIN were extracted by centrifugation at $1800 \mathrm{rpm}(450 \times \mathrm{g})$ for $10 \mathrm{~min}$. Subsamples of $1.8 \mathrm{ml}$ were analyzed immediately for $\mathrm{TCO}_{2}$ by the flow injection/diffusion cell technique (Hall \& Aller 1992) on a Kontron Ion Liquid Chromatograph, while the rest was frozen for later analysis of DIN as described above.

The solid phase was analyzed for water content as loss of weight after drying at $105^{\circ} \mathrm{C}$ overnight. Subsamples of the dried sediment were subsequently used for determination of organic content measured as particulate organic carbon (POC) and nitrogen (PON) on a Carlo Erba EA 1108 elemental analyzer. The concentration of chl $a$ in the sediment was determined by extracting $2 \mathrm{~g}$ wet subsamples in $5 \mathrm{ml}$ of $100 \%$ acetone overnight at $5^{\circ} \mathrm{C}$. The extract was centrifuged at $3000 \mathrm{rpm}(1200 \times \mathrm{g})$ for $10 \mathrm{~min}$ and the supernatant analyzed spectrophotometrically at 665 and $750 \mathrm{~nm}$ before and after adding 2 drops of $2 \mathrm{M} \mathrm{HCl}$ according to Parsons et al. (1984).

Worms recovered during sectioning were collected and weighed. Worm growth rates were calculated as the difference between mean initial and final weights according to Vedel \& Riisgård (1993).

Worm ventilation, respiration and $\mathrm{NH}_{4}{ }^{+}$excretion. Ventilation activity, $\mathrm{O}_{2}$ respiration and $\mathrm{NH}_{4}{ }^{+}$excretion were measured on individual worms of both species.
The worms were placed in U-shaped glass tubes in 2 separate $20 \mathrm{l}$ aquaria at $15^{\circ} \mathrm{C}_{i} 1$ without and 1 with algal additions (10000 Rhodomonas sp. cells $\left.\mathrm{ml}^{-1}\right)$. Ventilation activity was continuously monitored by attaching a flow probe $(2 \mathrm{~mm}$ i.d.) connected to an electromagnetic flowmeter on the excurrent opening of the tubes (Kristensen 1989). Ventilation is presented as pumping rate during active periods $\left(V_{w}\right)$, and duration of ventilation periods as the percentage of total measured time, $D_{v}(\%)$, and as the average duration in minutes, $D_{v}$ (min).

Oxygen respiration of actively ventilating worms was determined simultaneously as oxygen extraction during water passage through the glass tube. Samples of excurrent burrow water were continuously siphoned through an oxygen electrode (Radiometer, Copenhagen) at a known rate. Output signals from both ventilation and oxygen systems were recorded on a Phillips PM8220 dual-pen recorder. Calibrations of the system and calculation of ventilation activity and oxygen respiration were done according to Kristensen (1989). Ammonium excretion was determined as the difference in ammonium concentration of incurrent and excurrent water samples taken at short intervals during active ventilation.

\section{RESULTS}

\section{Visual observations}

Both types of control sediment (C, AC) exhibited a smooth surface throughout the experiment with a brownish oxidized zone down to $1.5 \mathrm{~cm}$ depth in treatments without, and 0.6 to $0.8 \mathrm{~cm}$ with, phytoplankton in the water column. In sediment containing Nereis diversicolor $(\mathrm{D}, \mathrm{AD})$, the surface became irregular and rough after a few days, with an oxidized zone of about $2 \mathrm{~cm}$ depth. Burrows of $N$. diversicolor had chimneylike openings extending 0.5 to $1 \mathrm{~cm}$ above the sediment surface when phytoplankton were present in the water column, whereas these structures were missing in the absence of algae. $N$. virens never produced such chimney-like structures. The sediment in the $N$. virens treatments (V, AV) was oxidized to $1-2 \mathrm{~cm}$ depth. The surface was rather smooth without phytoplankton, but was more irregular with feeding traces when phytoplankton was present in the water column. Burrows of both species extended to $9 \mathrm{~cm}$ without, and 11 to $13 \mathrm{~cm}$ depth with, phytoplankton in the overlying water. Sediment surrounding worm burrows of $N$. diversicolor was generally more oxidized ( 7 to $11 \mathrm{~mm}$ layer) than those of $N$. virens ( $<2 \mathrm{~mm}$ layer). The oxidized zones around $N$. diversicolor burrows were deepest in the algal-treated systems. 


\section{Clearance, ventilation and growth}

The presence of phytoplankton in the water column affected the ventilation pattern of the 2 nereids in opposite directions. The time-integrated ventilation of Nereis diversicolor individuals was enhanced almost 4 -fold in the presence of algae (AD) compared with the non-algae (D) situation (Table 1). This was due to increases in the ventilation amplitude and the total duration of ventilation activity. For $N$. virens individuals the time-integrated ventilation rate was reduced to $1 / 3$ in the presence of algae (AV) due to both decreasing
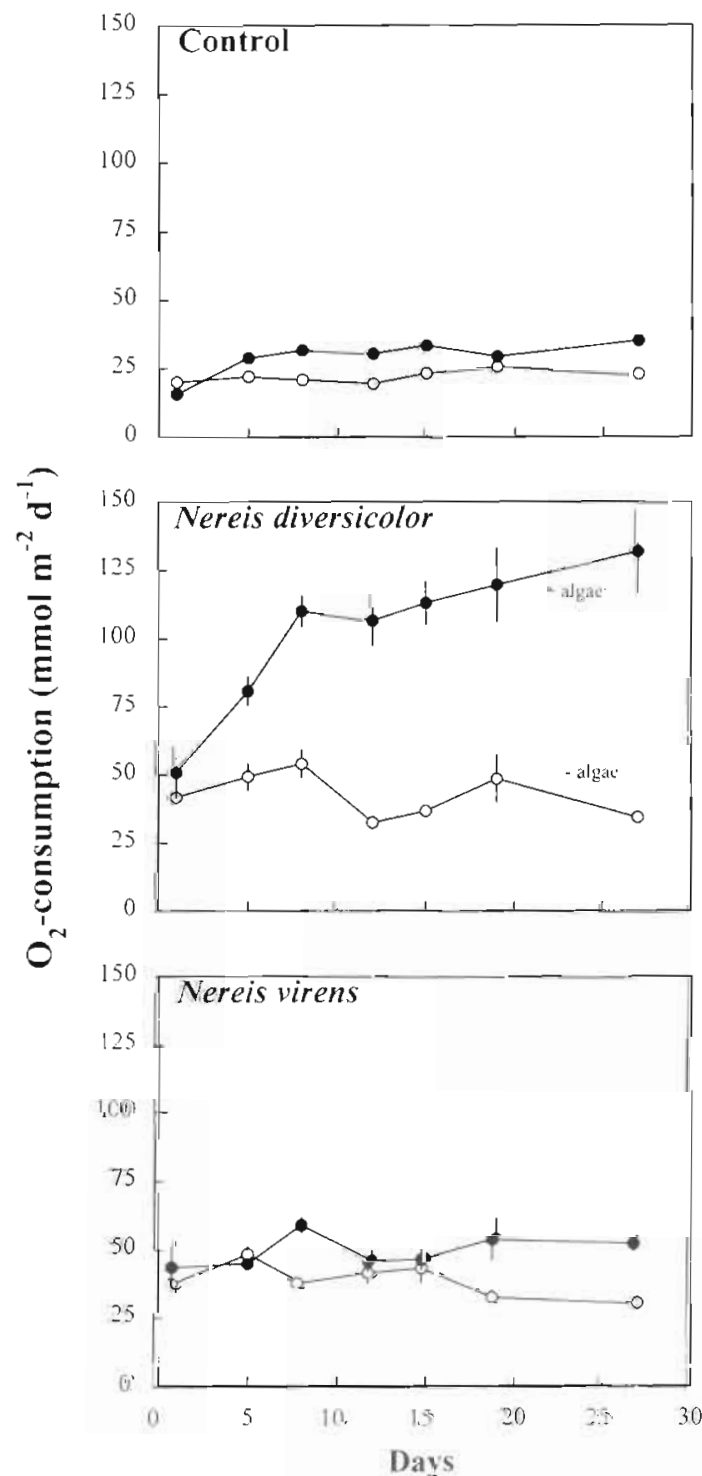

Fig. 1. Oxygen uptake in control, Nereis diversicolor and $N$ virens sediment with $(\bullet)$ and without $(0)$ addition of Rhodomonas sp. (algae) in the overlying water throughout a $27 \mathrm{~d}$ experimental period. Values are presented as mean $\pm \mathrm{SD}(\mathrm{n}=3)$ amplitude and duration of ventilation periods. The ventilation activity of $N$. diversicolor was always considerably higher than $N$. virens, i.e. 44 (AD:AV) and 4 $(D: V)$ times. In the tank with phytoplankton, high ventilation and filtration activity of the $N$. diversicolor (AD) population (600 ind. $\mathrm{m}^{-2}$ ) resulted in a 30 -fold higher clearance than for both the non-suspension-feeding $N$. virens (AV) population (600 ind $\mathrm{m}^{-2}$ ) and the defaunated control (AC) (Table 1). Thus, passive sedimentation of algae in the AV and $A C$ treatments was nearly similar. Since carbon and nitrogen content of Rhodomonas sp. were similar in all treatments, $3.9 \times 10^{-6}$ mol C cell- ${ }^{-1}$ and $7.1 \times 10^{-7} \mu \mathrm{mol} \mathrm{N}$ cell $^{-1}$ (equivalent to a molar C:N ratio of 5.5), the downward transport of organic $C$ and $N$ was also enhanced 30 -fold by the $N$. diversicolor population.

The presence of phytoplankton in the water column allowed Nereis diversicolor and $N$. virens to sustain positive growth with rates of 3.46 and $0.29 \% \mathrm{~d}^{-1}$, respectively. When no phytoplankton was present in the water column, the growth was negative with rates of -0.36 and $-0.89 \% \mathrm{~d}^{-1}$, respectively.

\section{Sediment-water fluxes}

Addition of algae to the water phase affected sediment $\mathrm{O}_{2}$ consumption rates most when Nereis diversicolor was present (Fig. 1). After an initial increase, $\mathrm{O}_{2}$ uptake by the $A D$ sediment stabilized after Day 7 at a level which was about 3 times higher than in the $D$ treatment The algal-treated $\mathrm{AV}$ and $\mathrm{AC}$ sediments both consumed about $40 \%$ more $\mathrm{O}_{2}$ than their algalfree counterparts ( $V, C$ ).

Unfortunately, measurements of $\mathrm{CO}_{2}$ release from the sediment failed due to storage and analytical problems. For use in carbon budgets, $\mathrm{CO}_{2}$ fluxes were therefore estimated from $\mathrm{O}_{2}$ fluxes by the use of respiratory quotient (RQ) values of 1.1 to 1.3 as found previously in our laboratory for this sediment type (Hansen \& Kristensen 1997). The use of a theoretical $R Q$ of 1.1 to 1.3 to convert $\mathrm{O}_{2}$ to $\mathrm{CO}_{2}$ fiuxes is debatable, but justifiable. Flux studies using organic-poor and sandy sediments from the same region as here have found comparably low $R Q$ values (i.e. 0.8 to 1.6; Kristensen et al. 1992, Kristensen 1993). A low RQ is characteristic of a sediment showing anaerobic respiration (e.g. sulfate reduction) with simultaneous oxidation of reduced motabolites (e.g. sulfide) (Andersen \& Krictensen 1988) Accordingly, the low pool sizes of total iron ( 1 to $2 \mu \mathrm{mol}$ $\left.\mathrm{cm}^{-3}\right)$ and reduced sulfides $\left(2\right.$ to $\left.5 \mu \mathrm{mol} \mathrm{cm}{ }^{-3}\right)$ found in these organic-poor sands (unpubl. data) indicate a low capacity for storage of reducing equivalents.

$\mathrm{NH}_{4}{ }^{*}$ release by the sediments was affected in a pattern similar to $\mathrm{O}_{2}$, except for a more rapid initial in- 
Table 1. Ventilation activity of individual worms placed in glass tubes (see 'Materials and methods' for further details). $V_{\mathrm{w}}$ : ventilation amplitude for 1 average sized $(\sim 400 \mathrm{mg})$ worm. Duration of ventilation is given as average period-length in minutes $\left(D_{v}[\min ]\right)$ and as percentage of total elapsed time: $\left(D_{v}[\%]\right)$. Time- and area-integrated ventilation is estimated as: $V_{w} \times D_{v}(\%) \times d$. where $d$ is the population density of nereids $\mathrm{m}^{-2}$ Average daily clearance is presented as the water volume cleared of algae. Corresponding removal of algal $\mathrm{C}$ and $\mathrm{N}$ from the water phase is determined by relating the change in concentration of algae cells $\mathrm{ml}^{-1}$ with their carbon and nitrogen content. $\mathrm{AC}, \mathrm{AD}$ and $\mathrm{AV}$; control, Nereis diversicolor and $N$. virens treatments with algae in the water column, respectively, whereas $D$ and $V$ : worm treatments without algae. Values for ventilation and $D_{v}$ are given as mean $\pm \mathrm{SE}(\mathrm{n}=3)$

\begin{tabular}{|lccccc}
\hline & AC & AD & D & AV \\
\hline Ventilation & & & & & \\
Amplitude, $V_{w}\left(\mathrm{ml} \mathrm{min}^{-1}\right)$ & - & $3.7 \pm 0.3$ & $2.4 \pm 0.3$ & $0.4 \pm 0.1$ & $0.8 \pm 0.0$ \\
$D_{v}(\mathrm{~min})$ & - & $5.9 \pm 1.1$ & $0.7 \pm 0.9$ & $7.1 \pm 0.7$ & $9.6 \pm 2.4$ \\
$D_{\mathrm{v}}(\%)$ & - & $85 \pm 2$ & $54 \pm 19$ & $42 \pm 17$ & $39 \pm 3$ \\
Integrated $\left(\mathrm{l} \mathrm{m}^{-2} \mathrm{~d}^{-1}\right)$ & - & $2704 \pm 185$ & $754 \pm 80$ & $62 \pm 9$ & $179 \pm 8$ \\
Clearance $\left(\mathrm{l} \mathrm{m}^{-2} \mathrm{~d}^{-1}\right)$ & 137 & 3711 & - & 4.9 & - \\
Cremoved $\left(\mathrm{mmol} \mathrm{m}^{2} \mathrm{~d}^{-1}\right)$ & 5.3 & 144.7 & - & 0.89 \\
N removed $\left(\mathrm{mmol} \mathrm{m}^{-2} \mathrm{~d}^{-1}\right)$ & 0.97 & 26.3 & & - \\
\hline
\end{tabular}

crease in the $\mathrm{AD}$ treatment (Fig. 2). The average $\mathrm{NH}_{4}^{+}$ release by the $\mathrm{AD}$ sediment from Day 7 onwards was 3.5 times higher than by the algal-free $\mathrm{D}$ sediment. The algal-treated AV sediment produced $50 \%$ more $\mathrm{NH}_{4}{ }^{+}$ than the algal-free $V$ sediment. There was no significant difference in $\mathrm{NH}_{4}{ }^{+}$release between control sediments with and without phytoplankton added to the overlying water. The exchange of $\mathrm{NO}_{3}{ }^{-}$was directed out of the sediment in all treatments (Fig. 3). The flux varied considerably during the first $15 \mathrm{~d}$ in $\mathrm{AD}$ sediment, but appeared to stabilize towards the end at a level 3 times higher than in the D sediment. Rates remained relatively constant in all other treatments. The average release of $\mathrm{NO}_{3}{ }^{-}$from Day 7 onwards was about 70 and 200\% higher in $\mathrm{AV}$ and $\mathrm{AD}$ sediment, respectively, than in the equivalent systems devoid of algae. Molar $\mathrm{CO}_{2}$ :DIN flux ratios (average, Day 7 onwards) based on converted $\mathrm{CO}_{2}$ fluxes and measured DIN $\left(\mathrm{NH}_{4}{ }^{+}+\mathrm{NO}_{3}{ }^{-}\right)$fluxes ranged between 6 and 11 in all treatments; lowest in Nereis diversicolor with algae (AD) and highest in $N$. virens without algae (V) (Table 2).

Oxygen uptake by Nereis diversicolor and $N$. virens, which was extrapolated from single worms in glass tubes to the population density (600 ind. $\mathrm{m}^{-2}$ ) used in the core experiment (Table 3), accounted for about $15 \%$ of the total sediment $\mathrm{O}_{2}$ demand in the algal-free treatments, but changed by the presence of algae to about $30(\mathrm{AD})$ and $10 \%(\mathrm{AV})$. Excretion of $\mathrm{NH}_{4}{ }^{+}$by the worms (Table 3 ) accounted for about 20 (D) and $50 \%$ (V) of the total DIN release in the algal-free treatments,

Fig. 2. Ammonium release in control, Nereis diversicolor and $N$. virens sediment with $(\bullet)$ and without $(0)$ addition of $R$ hodomonas sp. (algae) in the overlying water throughout a $27 \mathrm{~d}$ experimental period. Values are presented as mean $\pm \mathrm{SD}(\mathrm{n}=3)$
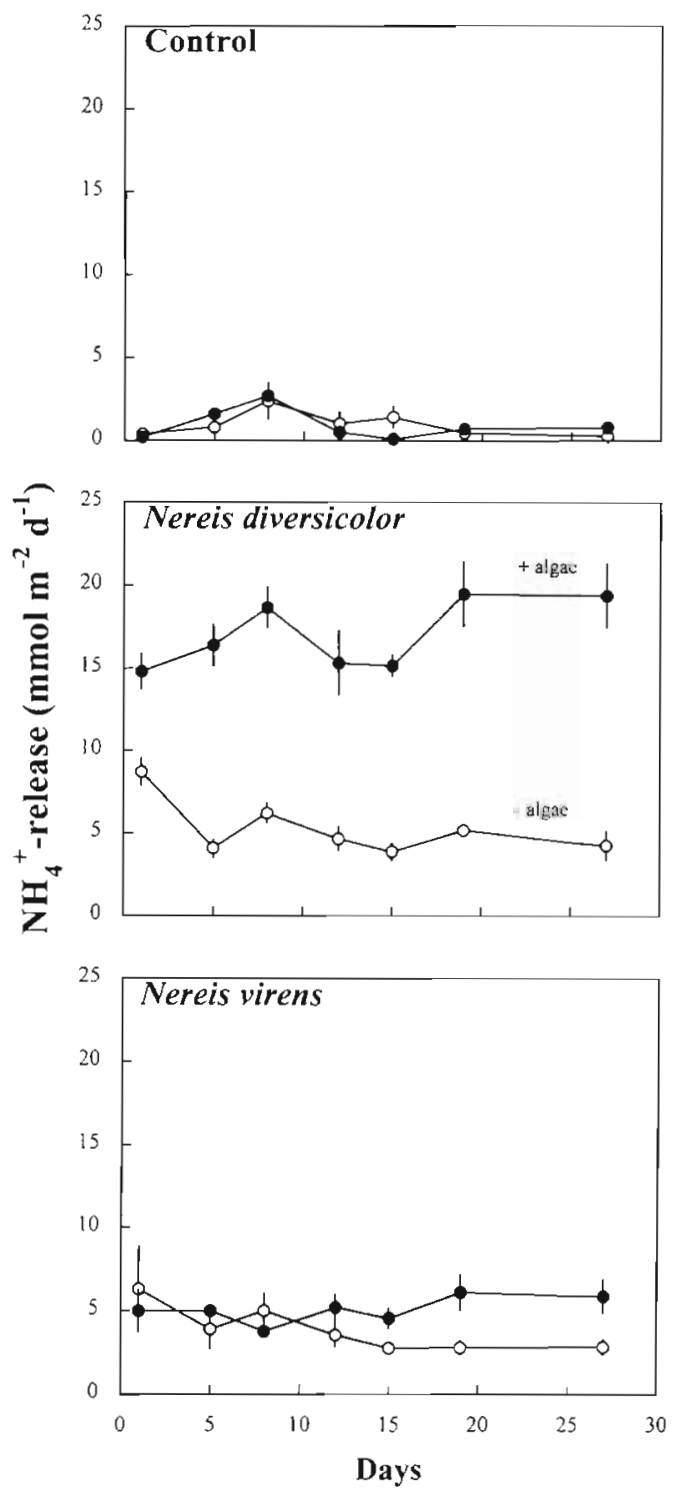
Table 2. C:N stoichiometry of fluxes after Day 7 with and without worm contribution given as $\Delta \mathrm{CO}_{2}: \Delta D I N$ flux ratios, where $\Delta C \mathrm{O}_{2}$ is estimated from $\Delta \mathrm{O}_{2}$ using a $\mathrm{RQ}$ of 1.1 to 1.3 (see 'Results' for details). The final (Day 27) reaction stoichiometry $\left(R_{C} / R_{N}\right.$ ) of net mineralization in the sediment is derived from slopes of porewater plots: $\mathrm{TCO}_{2}$ versus $\mathrm{NH}_{4}{ }^{-}\left(\Delta T \mathrm{TCO}_{2}: \Delta \mathrm{NH}_{4}{ }^{4}\right.$, Fig. 8). Estimated $\mathrm{R}_{\mathrm{C}} / \mathrm{R}_{\mathrm{N}}$ values for faunated sediment are presented as a range determined by the possible transport coefficient ratios $\left(D_{C} / D_{N}=0.6\right.$ to 1.0$)$

\begin{tabular}{|cccccrc|}
\hline & $\mathrm{AC}$ & $\mathrm{C}$ & $\mathrm{AD}$ & $\mathrm{D}$ & $\mathrm{AV}$ \\
\hline$\Delta \mathrm{CO}_{2}: \Delta \mathrm{DIN}$ (+worms) & $7.8-9.2$ & $6.6-7.8$ & $5.8-6.9$ & $7.3-8.6$ & $8.5-10.0$ & $9.5-11.2$ \\
$\Delta \mathrm{CO}_{2} \Delta \mathrm{DIN}$ (-worms) & $7.8-9.2$ & $6.6-7.8$ & $5.2-6.1$ & $7.2-8.5$ & $10.2-12.1$ & $15.1-17.8$ \\
$\mathrm{C}: \mathrm{N}$ porewater $\left(\mathrm{R}_{\mathrm{C}} / \mathrm{R}_{\wedge}\right)$ & 4.5 & 4.8 & $2.7-4.5$ & $3.7-6.1$ & $4.3-7.2$ & $4.0-6.6$ \\
\hline
\end{tabular}
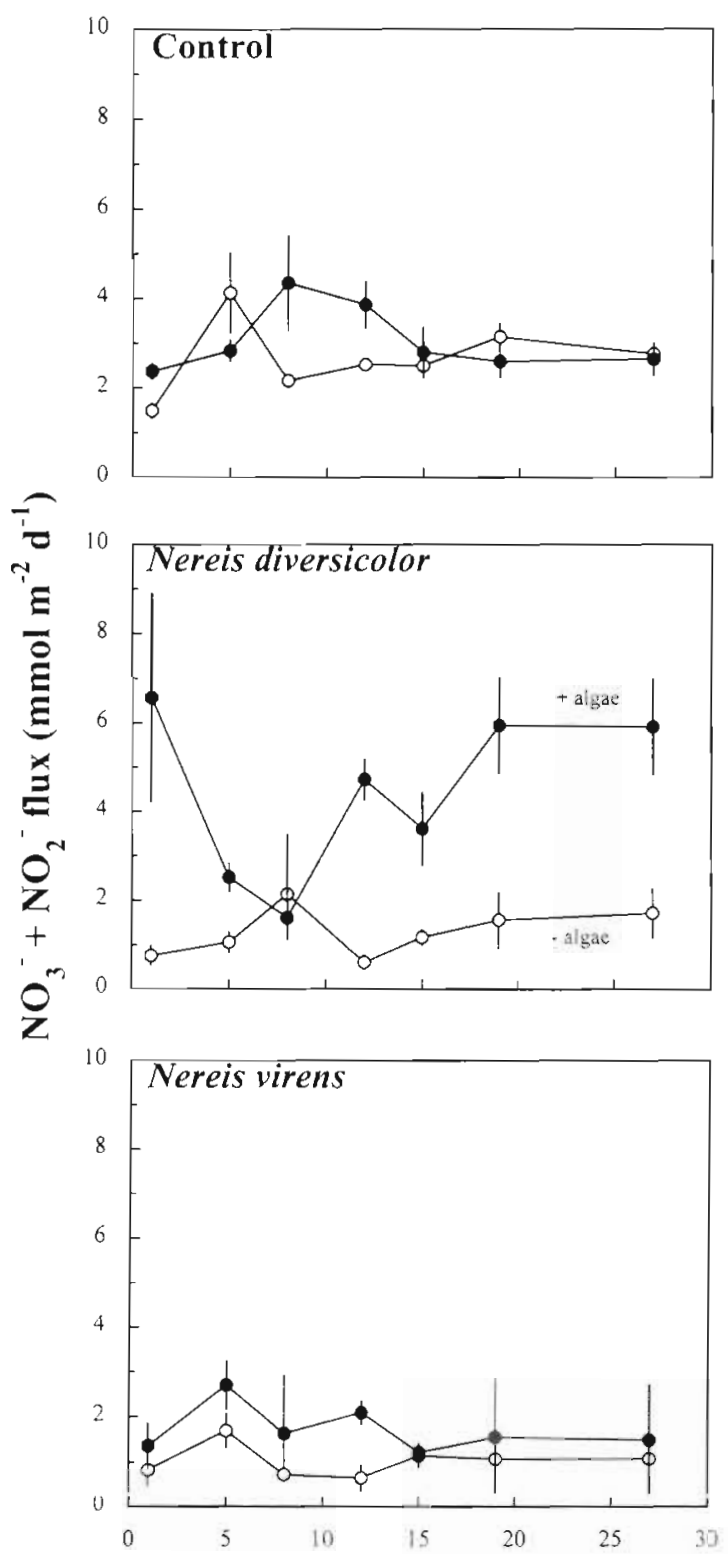

Fig. 3. Nitrate and nitrite release in control, Nereis diversicolor and $N$. virens sediment with $(0)$ and without $(0)$ adidion of Rhodomonas sp. (aigae) in the overlying water throughout a 27 d experimental period Values are presented as mean $\pm \mathrm{SD}(\mathrm{n}=3)$ whereas the worm contribution was about $20 \%$ for both species when phytoplankton was added. $\mathrm{CO}_{2}$ release by worms was estimated from $\mathrm{O}_{2}$ uptake by applying a $R Q$ of 1.2 (Kristensen 1989). The $C: N$ ratio of excretion products was 8 to 9 in $N$. diversicolor and about 3.5 in $N$. virens. After subtracting the direct worm contribution from the total fluxes in faunated sediment, the estimated microbially derived $\mathrm{CO}_{2}$ :DIN flux ratios became considerably higher in sediment containing $N$. virens ( $\mathrm{V}, \mathrm{AV}$ ) (Table 2). Subtraction of the faunal contribution in $N$. diversicolor (D, AD) treatments had only limited impact on $C: N$ flux ratios due to the similarity of sediment and animal $C: N$ flux ratios.

\section{Porewater profiles}

Profiles of dissolved $\mathrm{TCO}_{2}$ and $\mathrm{NH}_{4}{ }^{+}$increased steeply with depth in both types of control sediment (Fig 4). $\mathrm{TCO}_{2}$ concentrations increased from about $2 \mathrm{mM}$ in the water column to 24 (AC) and $29 \mathrm{mM}(\mathrm{C})$ at $10 \mathrm{~cm}$ depth, whereas $\mathrm{NH}_{4}{ }^{+}$concentrations increased from about $0.2 \mathrm{mM}$ to 3.0 (AC) and $3.6 \mathrm{mM}$ (C). Most solute profiles were affected considerably by animal activities. In the presence of actively suspension-feeding Nereis diversicolor (AD), the porewater concentration of $\mathrm{TCO}_{2}$ and $\mathrm{NH}_{4}{ }^{+}$hardly increased from the sediment surface to $10 \mathrm{~cm}$ depth and exhibited a level around 2 and $0.3 \mathrm{mM}$, respectively. When no phytoplankton was added to the water overlying $N$. diversi-

Table 3. Measured $\mathrm{O}_{2}$ consumption and $\mathrm{NH}_{4}{ }^{*}$ excretion by nereid worms in glass tubes. Data are given as area-specific rates (mriol $\mathrm{m}^{-2} \mathrm{~d}^{-1}$ ) by extrapolating to the population density $\left(600\right.$ ind. $\left.\mathrm{m}^{-2}\right)$ applied in the core experiment. Values are mean $\pm \operatorname{SE}(\mathrm{n}=3$ )

\begin{tabular}{|ccccc|}
\hline & AD & D & AV & V \\
\hline \begin{tabular}{lcccc}
\hline \\
Worm $\mathrm{O}_{2}$
\end{tabular} & $33.8 \pm 2.3$ & $7.6 \pm 0.8$ & $4.4 \pm 0.6$ & $5.5 \pm 0.2$ \\
$\begin{array}{l}\text { Consumption } \\
\text { excretion }\end{array}$ & $4.4 \pm 0.3$ & $1.1 \pm 0.1$ & $1.6 \pm 0.2$ & $2.0 \pm 0.2$ \\
\hline
\end{tabular}




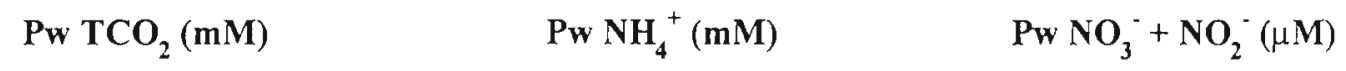
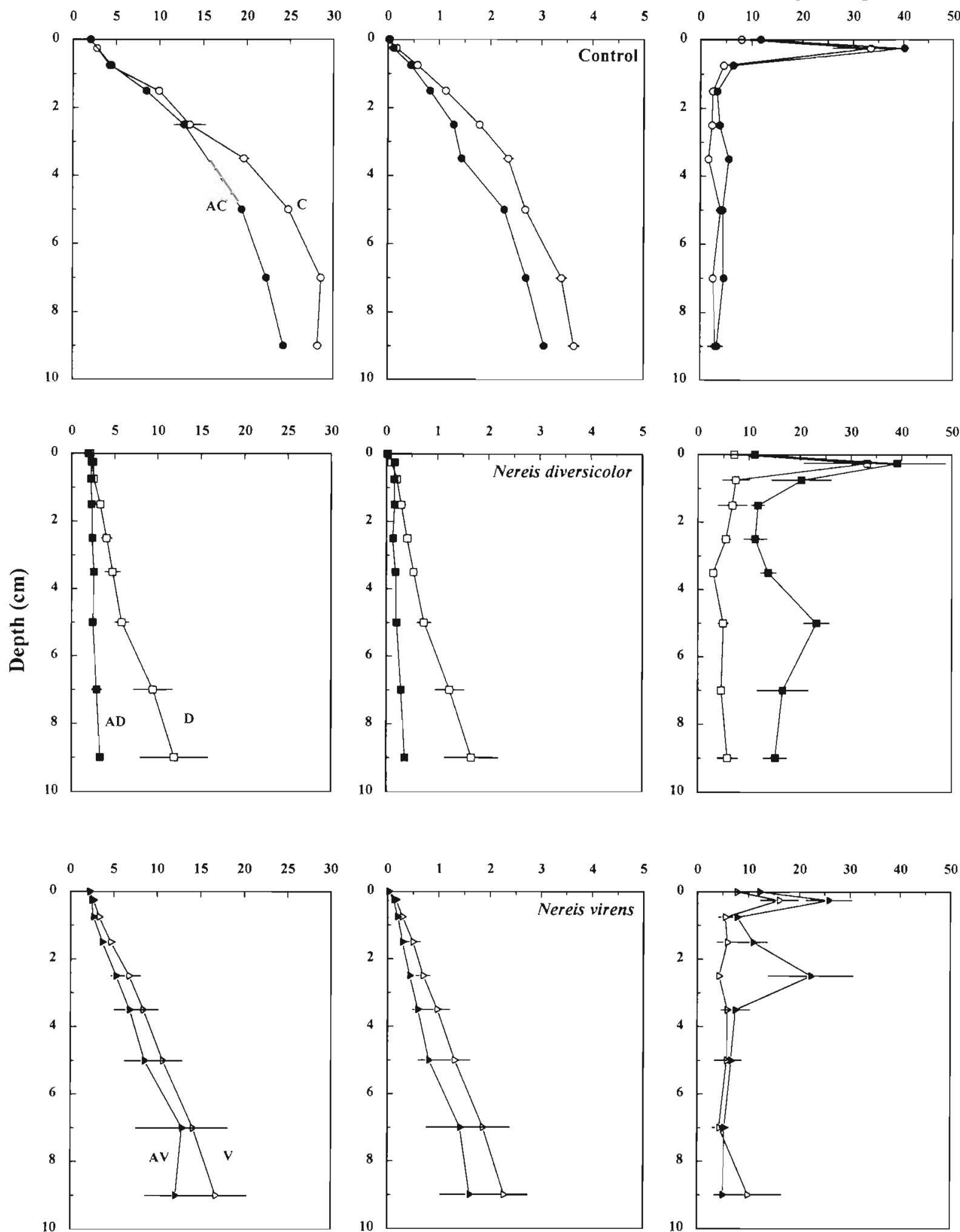

Fig. 4. Vertical profiles of porewater $\mathrm{TCO}_{2}, \mathrm{NH}_{4}{ }^{+}$and $\mathrm{NO}_{3}{ }^{-}$in control (AC, C), Nereis diversicolor (AD, D) and $N$. virens (AV, $\mathrm{V}$ ) sediment with (solid symbols) and without (open symbols) addition of Rhodomonas sp. (algae) in the overlying water. Values are presented as mean $\pm \mathrm{SD}(\mathrm{n}=3)$. Data from the control treatment with algae $(\mathrm{AC})$ are only based on 1 determination 


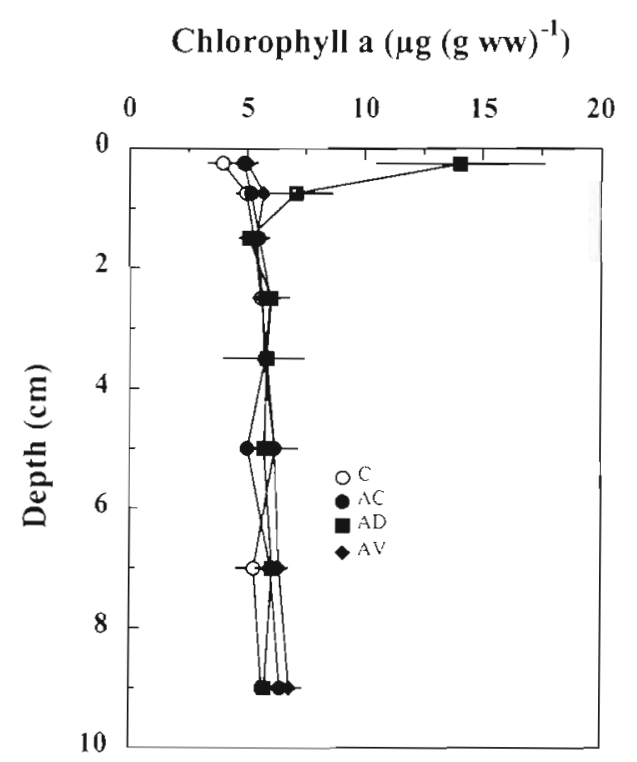

Fig. 5. Vertical profiles of chl a in control sediment with (AC) and without (C), and Nereis diversicolor (AD) and N. virens (AV) sediment with addition of Rhodomonas sp. (algae) in the overlying water. Values are presented as mean $\pm S D(n=3)$. Data for the AC treatment are only based on 1 determination

color sediment (D) the porewater concentration of $\mathrm{TCO}_{2}$ and $\mathrm{NH}_{4}{ }^{+}$increased gradually with depth to 12 and $2 \mathrm{mM}$, respectively. Porewater profiles of $\mathrm{TCO}_{2}$ and $\mathrm{NH}_{4}{ }^{+}$from sediment containing $N$. virens both without (V) and with (AV) algae were comparable to those of the $\mathrm{D}$ sediment. There was no significant difference between $N$. virens treatments (AV, V) for any of the measured porewater solutes.

Porewater profiles of $\mathrm{NO}_{3}$ generally showed depth patterns of similar shape regardless of treatment (Fig 4). In all cases there was a peak at $0.5 \mathrm{~cm}$ depth with concentrations of 30 to $40 \mu \mathrm{M}$ in both types of control (C, AC) and Nereis diversicolor (D, AD) sediment. However, somewhat lower peak values (15 to $25 \mu \mathrm{M}$ ) were detected in $N$. virens ( $V$, AV) sediment. Below $0.5 \mathrm{~cm}$ the concentrations decreased to a constant level of 2 to $5 \mu \mathrm{M}$ in all treatments devoid of algae $(C, D, V)$ and the control treatment with algae (AC). A subsurface peak of about $20 \mu \mathrm{M}$ was evident at 2 to $3 \mathrm{~cm}$ depth in $N$. virens (AV) sediment with algae. The concentrations of $\mathrm{NO}_{3}$ below $0.5 \mathrm{~cm}$ in algal-treated $\mathrm{N}$. diversicolor (AD) sediment remained between 10 and $20 \mu \mathrm{M}$ with a subsurface peak around $5 \mathrm{~cm}$ depth.

\section{Sediment characteristics}

The chl a content of the sediment was almost constant, around $5.5 \mathrm{\mu g} \mathrm{g}^{-1}$ wet wt with depth in all treatments. The only exception was a 3 -fold increase in the upper $0.5 \mathrm{~cm}$ of Nereis diversicolor sediment when phytoplankton was present in the water column (Fig. 5).

Pools of POC in the upper $0.5 \mathrm{~cm}$ of the sediment ranged from 167 to $183 \mu_{\mathrm{mol} \mathrm{g}}^{-1}$ dry wt, and those of PON from 15 to $19 \mu \mathrm{mol} \mathrm{g}^{-1}$ dry $w \mathrm{t}$, except for a significant 36 and $42 \%$ increase, respectively, in the presence of both Nereis diversicolor and algae (AD). Bulk sediment $\mathrm{C}: \mathrm{N}$ ratios in all treatments were about 8.8 .

\section{DISCUSSION}

The 2 closely related nereid species Nereis diversicolor and $N$. virens are widely different with respect to their impact on transport processes and chemical reactions in sediments. The present experiments demonstrate that the suspension-feeding capacity of $N$. diversicolor may enhance phytoplankton deposition by more than 1 order of magnitude and benthic metabolism several-fold compared with the deposit-feeding $N$. virens. However, since only situations with 1 density of animals in allopatry subjected to a constant phytoplankton concentration under a well-stirred water column were applied for comparative purposes, direct extrapolations of the experimental results to natural conditions in the field should be made with caution.

\section{Feeding modes}

The chimney-like extensions of Nereis diversicolor burrows when phytoplankton is present in the overlying water appear. to be indicators of active suspensionfeeding by this species. Clearance estimated for $N$. diversicolor (Table 1) is comparable to in situ values previously obtained for populations of this species (4.6 to $9.8 \times 10^{3} \mathrm{l} \mathrm{m}^{-2} \mathrm{~d}^{-1}$ ) (Riisgård 1991, Vedel \& Riisgård 1993). The concentration of 10000 Rhodomonas sp. cells $\mathrm{ml}^{-1}$ corresponds to $12.5 \mu \mathrm{g} \mathrm{chl} \mathrm{a} \mathrm{l^{-1 }}$ (Vedel \& Riisgard 1993), which is within the range of chl a in the water column of Kertinge Nor during productive periods (particularly spring and autumn with 10 to $50 \mu \mathrm{g}$ chl a l-1 Riisgard et al. 1995). A phytoplankton concentration of this magnitude is known to support a growth rate of $N$. diversicolor around $3.9 \% \mathrm{~d}^{-1}$ (Vedel \& Riisgård 1993), which is almost identical to the growth found here for suspension-feeding individuals of this species. The retention of particulate carbon and nitrngen by suspension-feeding $N$. diversicolor was evident in the upper $0.5 \mathrm{~cm}$ of the sediment, where the organic content was about $40 \%$ higher than in the other treatments. The phytoplankton origin of the excess organic matter is substantiated by an almost 3 -fold increase in chl a content near the sediment surface (Fig. 5). It may 
be argued, however, that natural populations of $N$. diversicolor rarely experience high phytoplankton concentrations. Recent studies have demonstrated that suspension-feeding by dense $N$. diversicolor populations may reduce phytoplankton concentrations by up to $50 \%$ in the near-bottom water layer $(5$ to $10 \mathrm{~cm}$ ) on calm days (Riisgaård et al. 1996, Vedel 1998). Thus, effective vertical mixing by waves and currents is extremely important for dense populations of this worm to realize their great suspension-feeding potential.

The disturbed sediment surface in the Nereis virens system with phytoplankton in the overlying water indicates that this species acted as a surface deposit feeder on passively deposited algae. The substantial reduction in ventilation activity when algae were present also indicates that individuals of this species spent more time as active deposit feeders at the surface than in the situation without algae. However, $N$. virens was only able to sustain a growth rate of less than $10 \%$ of $N$. diversicolor due to limited food supply even when phytoplankton was present in the system. Both nereid species lost weight when phytoplankton was absent in the water column due to exhaustion of food resources. The higher ventilation activity of $N$. diversicolor than $N$. virens in this situation (Table 1) may be an inherent mechanism that triggers the former species to conduct frequent suspension-feeding cycles to test for available phytoplankton, and thus increases water transport above the level needed for maintaining living conditions in the burrow (Nielsen et al. 1995). A sufficient and variable food supply is usually available for a deposit feeder, like $N$. virens, in the natural environment. The high abundance of microphytobenthos and macroalgal detritus, as well as live and dead invertebrates found in shallow coastal sediments, represents a sufficient food source for this species and also for $N$. diversicolor during phytoplankton-poor periods (Goerke 1971).

\section{Benthic metabolism}

The activities of Nereis diversicolor and $N$. virens considerably enhance the sediment-water exchange of $\mathrm{O}_{2}\left(\mathrm{CO}_{2}\right)$ and $\mathrm{NH}_{4}{ }^{+}$. The faunal stimulation of benthic metabolism in the algal-free situation $\left(\mathrm{O}_{2}\right.$ uptake by a factor of 2 and $\mathrm{NH}_{4}{ }^{+}$release by a factor of 4 to 5) is comparable to previous values reported from organic-poor sediment inhabited by $N$. diversicolor (Hansen \& Kristensen 1997) or $N$. virens (Kristensen \& Blackburn 1987). The worms themselves also contribute to the total benthic metabolism by feeding, assimilation and respiration. The respiratory requirement and $\mathrm{NH}_{4}{ }^{+}$excretory capacity of the polychaetes accounted for a minor ( 10 to $20 \%$ ) part of the total sediment $\mathrm{O}_{2}$ uptake and DIN release, but generally up to half of the faunalinduced flux enhancement. The remainder of the enhanced fluxes was due to stimulated microbial processes in the sediment surrounding burrows (Marinelli \& Boudreau 1996). Other studies have also reported that the contribution of Nereis spp. to total benthic metabolism is around 20\% (Andersen \& Kristensen 1988, Kristensen et al. 1992). A number of mechanisms have been suggested as being responsible for the faunal-induced enhancement of microbial metabolism and capacity for organic matter degradation in sediments, e.g. redistribution of particles, enhanced porewater transport, and secretions of labile mucus along burrow walls (Wheatcroft et al. 1994, Marinelli \& Boudreau 1996, Aller \& Aller 1998).

The stronger impact of suspension-feeding Nereis diversicolor than deposit-feeding $N$. virens on benthic metabolism after addition of phytoplankton to the water phase (Figs. 1 to 3 ) is partly caused by high microbial activity in burrow walls associated with enhanced deposition of algae and fecal pellets. Accordingly, we have found higher organic content and microbial decomposition rates in burrow linings of $N$. diversicolor than those of $N$. virens from a natural environment with phytoplankton in the overlying water (unpubl. data). However, the abundant supply of nutritious food for $N$ diversicolor also increased the worms' own metabolism considerably (Table 3). The nutritional state therefore appears to be an important endogenous factor influencing the metabolism of polychaetous annelids (Cammen 1987, Kristensen 1989), and thus total benthic metabolism.

The generally high $\mathrm{NH}_{4}{ }^{+}$excretion by Nereis virens was probably caused by utilization of body proteins for the metabolism (Regnault 1981), because this depositfeeding worm was in a more or less starved condition irrespective of algal presence in the overlying water. The relatively higher $\mathrm{NH}_{4}{ }^{+}$excretion of starved $N$. virens than of suspension-feeding $N$. diversicolor was expected, but the low excretion of starved $N$. diversicolor is puzzling. Starved individuals of this species may, to a larger extent than $N$. virens, lose excess nitrogen in dissolved organic form (e.g. urea; O'Malley \& Terwilliger 1975) or via secretion of protein-rich mucus for filter construction.

\section{Porewater relations}

The impact of nereid polychaetes on transport conditions in the sediment is evident as significantly displaced porewater profiles in systems with animals (Fig. 4). A similar strong influence of infaunal ventilation on the concentration and transport of porewater solutes have been observed frequently in coastal 

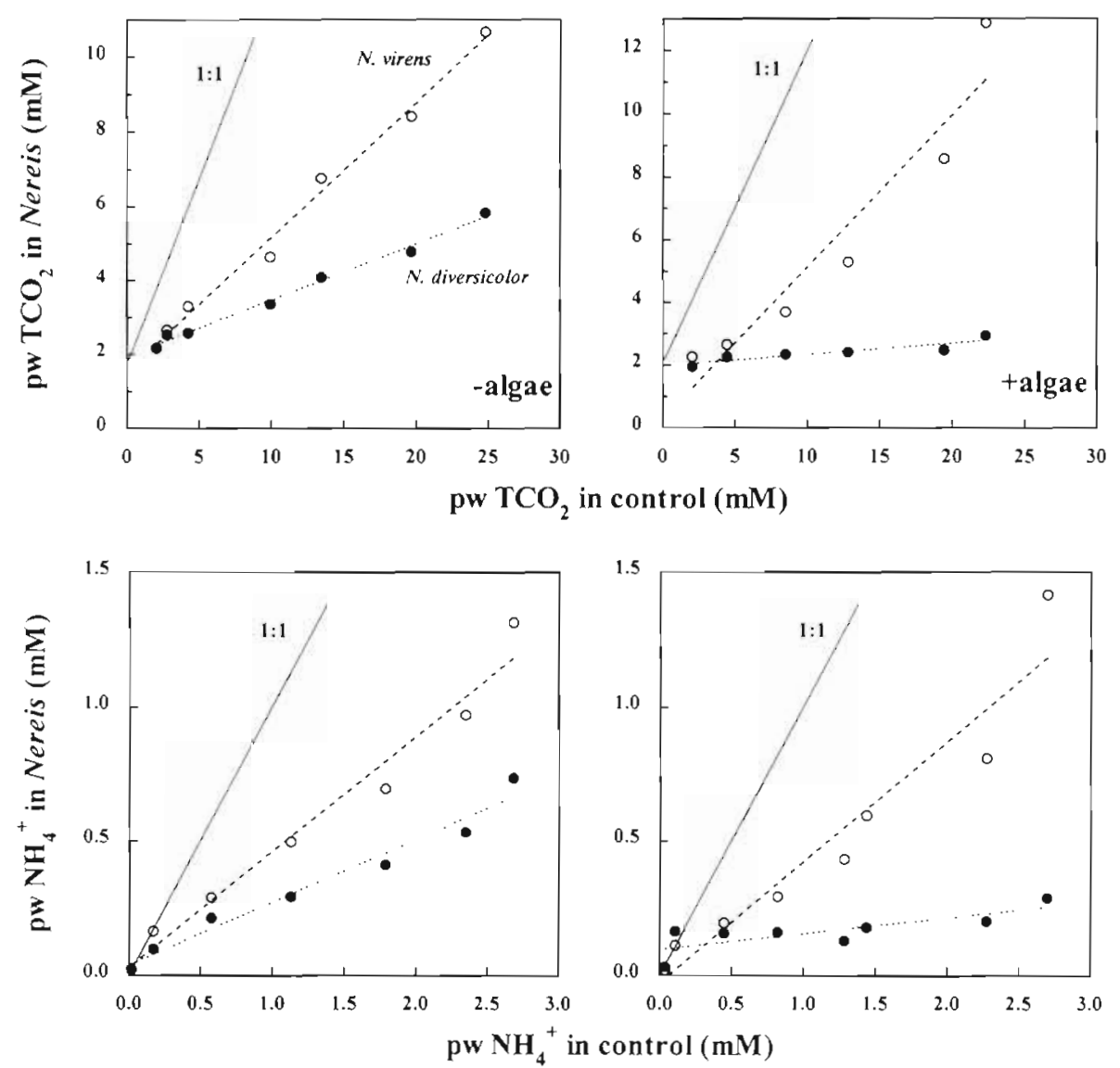

Fig. 6. Relationship between solute concentration $\left(\mathrm{TCO}_{2}\right.$ and $\mathrm{NH}_{4}{ }^{+}$) in the porewater of control sediment and the corresponding Nereis diversicolor $(\cdots \cdots \cdot)$ or N. virens (-......) treated sediment. Left panels: systems without (-algae); right panels: with (+algae) phytoplankton in the overlying water Lines are drawn according to least-squares linear regression. 1:1 lines are shown for comparison (displaced 2 mM upward in the $\mathrm{TCO}_{2}$ plots)

marine sediments (Aller \& Yingst 1985, Huettel 1990, Kristensen \& Hansen 1999). The lower concentrations of $\mathrm{TCO}_{2}$ and $\mathrm{NH}_{4}{ }^{+}$found in the algal-treated, compared with the non-algal-treated, controls may be caused by a stimulated growth and activity of bioturbating meiofauna and small polychaetes in the surface layer of sediments underlying a phytoplankton-rich water column (Aller \& Aller 1992). Enhanced solute transport in the uppermost sediment layer will always be reflected as displaced porewater profiles deeper in the sediment.

Porewater profiles of diagenetically active solutes in sediments are basically controlled by a balance between microbially derived reaction rates and the prevailing transport conditions (Aller 1982). The solute profiles in the present experiment were clearly affected by diffusion down to at least 6 to $8 \mathrm{~cm}$ depth in control sediments, and by Nereis-induced transport to at least $10 \mathrm{~cm}$ depth in faunated sediments. The upper 6 to $10 \mathrm{~cm}$ of the sedirnent can therefore he consjdered an open, diffusion-dominated zone approaching steady state (Aller \& Mackin 1989, Kristensen \& Hansen 1999). Although the absolute concentrations are different, the basic shape of porewater profiles of $\mathrm{TCO}_{2}$ and $\mathrm{NH}_{4}{ }^{*}$ should be independent of infaunal activity within the bioturbated zone when reaction and transport rates are assumed constant with depth (Kristensen \& Hansen 1999). Transport conditions in the examined depth interval $(0$ to $10 \mathrm{~cm}$ ) should be depthindependent in the Nereis-inhabited sediment as suggested by a burial depth of about $10 \mathrm{~cm}$. Because the sediment was initially homogenized in the present study, the reaction rates (or $\mathrm{CO}_{2}$ and $\mathrm{NH}_{4}{ }^{+}$production) are also approximated as depth-independent and constant. This was shown in a similar experiment by Kristensen \& Hansen. (1995). The above assumptions are substantiated by the more or less linear relationship between porewater $\left(\mathrm{TCO}_{2}\right.$ and $\left.\mathrm{NH}_{4}{ }^{+}\right)$profiles in Nereis-inhabited and control sediment (Fig 6). Slopes lower than unity indicate a faster removal of solutes due to ventilation transport via burrows than by molecular diffusion. The minor curvature observed for some $N$. virens cases in Fig. 6 is probably caused by a slight decrease in ventilation activity, and thus reduced colute trancport in the deenest part of the examined depth interval.

The average porewater concentration in bioturbated sediments is generally considered to depend on the size and abundance of infauna (Aller 1982). However, the ventilation activity varies considerably between irifaunal species (Kristenseñ 1988) and may 
depend on the feeding mode within a single species, as observed here for both Nereis diversicolor and $N$. virens (Table 1). The buildup of porewater solutes may therefore, in addition to size and density, also be a function of total population ventilation activity. The direct relationship between ventilation rate of our nereid populations of a fixed size and porewater concentrations is clearly demonstrated in Fig. 7. Slopes of porewater $\left(\mathrm{TCO}_{2}\right.$ and $\left.\mathrm{NH}_{4}{ }^{+}\right)$plots between bioturbated and control sediments (from Fig. 6) decrease exponentially with population ventilation rate of the 2 nereid species studied here. The relationship was similar for both examined solutes at a fixed Nereis density of 600 ind. $\mathrm{m}^{-2}$ (porewater ratio $\left(\mathrm{TCO}_{2}\right)=$ $-0.122 \ln ($ ventilation $)+0.99, \mathrm{r}^{2}=0.99 ;$ porewater ratio $\left(\mathrm{NH}_{4}{ }^{+}\right)=-0.109 \ln ($ ventilation $\left.)+0.94, \mathrm{r}^{2}=0.95\right)$ and possibly also for other porewater constituents subject to zero order kinetics. Aller (1982) has shown similar relationships by a modelling approach, but he used population density as the independent variable instead of total population ventilation rate. However, future studies of infaunal impacts on solute transport in sediments should consider population ventilation as a key parameter when species composition, abundance and envirommental conditions change in time and space (Webster 1992, Marinelli 1994)

\section{Carbon and nitrogen stoichiometry}

It has been shown that the $\mathrm{C}: \mathrm{N}$ ratio of the mineralized organic matter may be ascertained from vertical steady-state porewater profiles of $\mathrm{TCO}_{2}$ and $\mathrm{NH}_{4}{ }^{+}$if simple stoichiometric decomposition following firstorder kinetics occurs (Berner 1977, Kristensen \& Hansen 1995). More specifically, the slope of $\mathrm{TCO}_{2}$ versus $\mathrm{NH}_{4}{ }^{+}$plots $\left(\triangle \mathrm{TCO}_{2} / \Delta \mathrm{NH}_{4}{ }^{+}\right)$multiplied with the ratio of sediment transport coefficients for $\mathrm{TCO}_{2}$ and $\mathrm{NH}_{4}{ }^{+}\left(\mathrm{D}_{\mathrm{C}} / \mathrm{D}_{\mathrm{N}}\right)$ provides an estimate of net carbon and nitrogen reaction stoichiometry $\left(\mathrm{R}_{C} / \mathrm{R}_{N}\right)$ within the sediment according to:

$$
\mathrm{R}_{\mathrm{C}} / \mathrm{R}_{\mathrm{N}}=\left(\Delta \mathrm{TCO}_{2} / \Delta \mathrm{NH}_{4}^{+}\right) \times\left(\mathrm{D}_{\mathrm{C}} / \mathrm{D}_{\mathrm{N}}\right)
$$

The ratio $D_{C} / D_{N}$ is 0.6 in defaunated sediment where molecular diffusion is the only transport process, and 1.0 when the transport is generated solely by porewater advection. Kristensen \& Hansen (1999) showed that solute transport in sediments inhabited by actively ventilating infauna is driven by a combination of diffusion (i.e. non-local exchange; Emerson et al. 1984) and biogenic porewater turbulence (i.e. effective diffusion, Berner 1980). Diffusion dominates in non-permeable muds, whereas both diffusion and porewater advection are important in permeable sandy sediments (Kristensen \& Hansen 1999). For the present sandy sediment

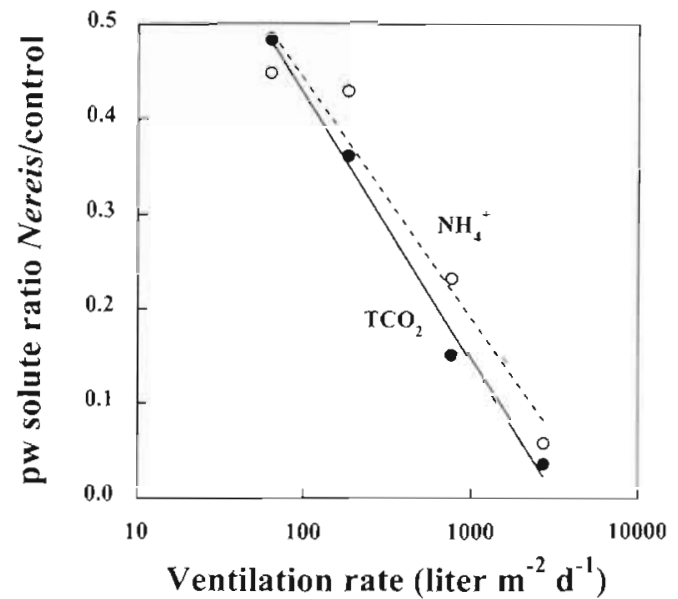

Fig. 7. Slopes of the relationship between porewater solute concentrations in control and Nereis-treated sediment as a function of nereid population ventilation rate. Lines are drawn according to least-squares linear regression. (-) $\left.\mathrm{TCO}_{2} ;(\ldots-)\right) \mathrm{NH}_{4}{ }^{+}$. Note the logarithmic ventilation scale

the effective ratio of transport coefficients $\left(D_{C} / D_{N}\right)$ is 0.6 in the control sediment and within a range of 0.6 and 1.0 in the faunated treatments. However, the exact value for the bioturbated sediment is unknown and depends on the ventilation activity of the worms.

A significant linear relationship between porewater $\mathrm{TCO}_{2}$ and $\mathrm{NH}_{4}{ }^{+}$is evident for all treatments (Fig. 8) providing slopes ranging from 4.4 (AD) to 8.0 (C). By assuming steady-state and no porewater advection, the $\mathrm{C}: \mathrm{N}$ reaction stoichiometry in defaunated sediments varies from 4.5 to 4.8 (Table 2). For the faunated sediments with an unknown degree of porewater advection, the $\mathrm{C}: \mathrm{N}$ reaction stoichiometry must range from $2.7-4.3\left(\mathrm{D}_{C} / \mathrm{D}_{\mathrm{N}}=0.6\right)$ to $4.5-7.2$ $\left(D_{C} / D_{N}=1.0\right)$. Low $C: N$ ratios such as those found here ( 3 to 7 ) have been observed in a number of studies (Berner 1977, Klump \& Martens 1987, Kristensen \& Hansen 1995), and indicate a preferential microbial degradation of organic nitrogen, since the bulk sediment C:N ratio usually is between 8 and 10 (8.8 in the present study). The rate and stoichiometry of organic matter decomposition in sediments are generally considered to be controlled by the size and chemical composition of the organic pool actually being degraded and not by the bulk sediment composition (Westrich \& Berner 1984, Kristensen \& Blackburn 1987). Particularly in the Nereis diversicolor treatment with algae, a sufficient source of labile protein was available from the retained algal cells $(\mathrm{C}: \mathrm{N}=5.5)$ to provide the very low $\mathrm{C}: \mathrm{N}$ reaction stoichiometry in this sediment.

The C:N stoichiometry of net organic matter mineralization within the sediment was always lower than 

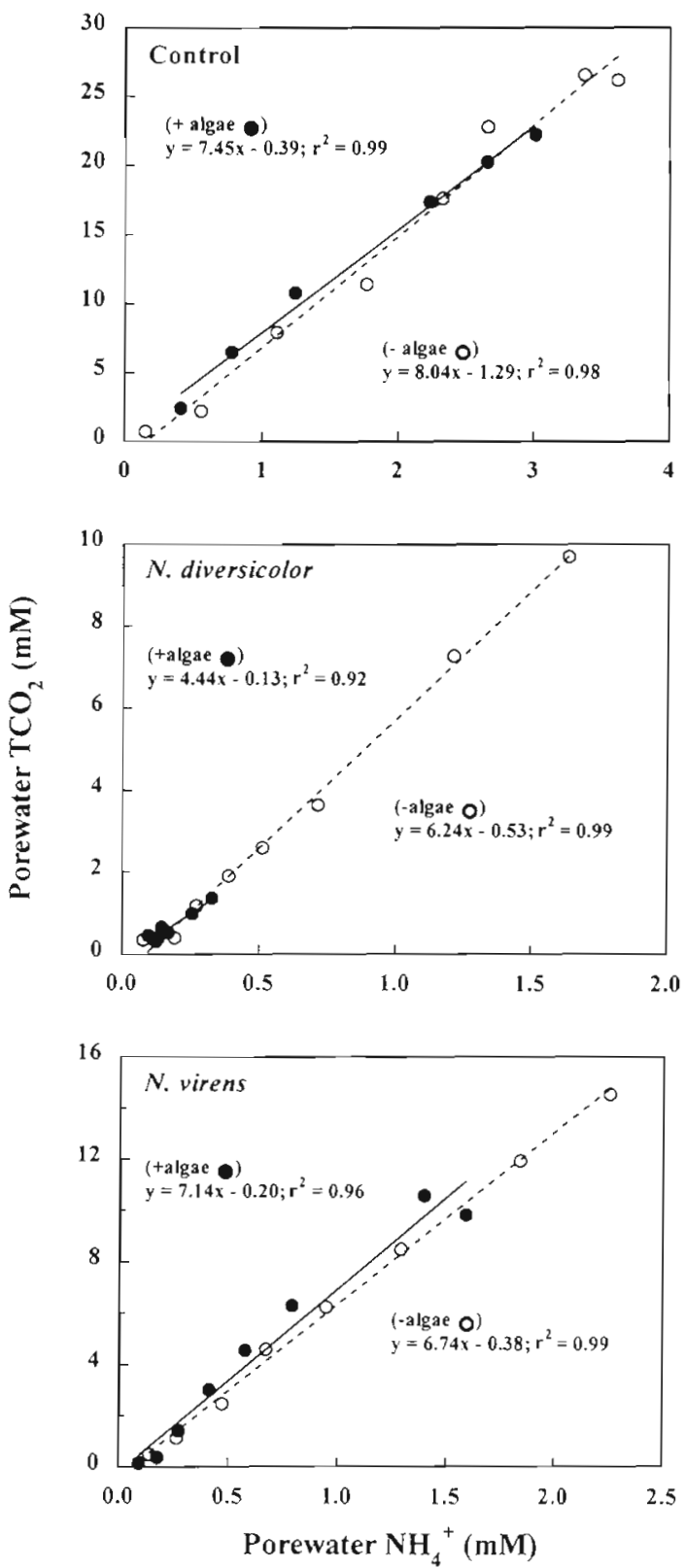

Fig. 8. Plots of porewater $\mathrm{NH}_{4}{ }^{-}$versus $\mathrm{TCO}_{2}$ in all treatments. Lines are fitted by least-squares linear regressions according to the equations given

for sediment-water fluxes (Fig. 9), indicating a net loss or retainment of nitrogen within the sediment. The missing nitrogen may either be lost as $\mathrm{N}_{2}$ via denitrification (Seitzinger 1988, Iove of a! 1996) or incorporated into the organic pool by bacterial assimilation (Blackburn 1988). The loss was apparently proportional to benthic metabolism as depicted from the almost constant deviation from the 1:1 line in the flux versus porewater C:N relationship (Fig. 9). The nitrogen loss in the algal-treated systems accounted

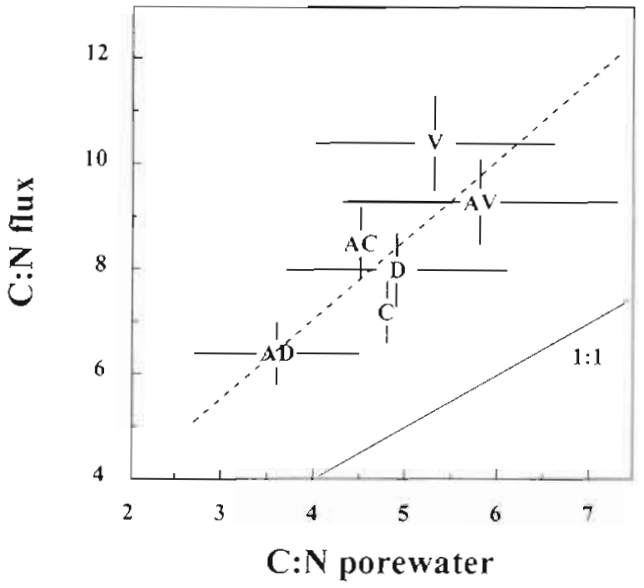

Fig. 9. Relationship between C:N stoichiometry of fluxes after Day $7\left(\Delta \mathrm{CO}_{2}: \Delta \mathrm{DIN}\right.$ flux ratios) and $\mathrm{C}: \mathrm{N}$ stoichiometry of the final (Day 27) reaction stoichiometry $\left(R_{C} / R_{N}\right)$ of net mineralization in the sediment derived from slopes of porewater plots: $\mathrm{TCO}_{2}$ versus $\mathrm{NH}_{4}{ }^{-}\left(\Delta \mathrm{TCO}_{2}: \Delta \mathrm{NH}_{4}{ }^{+}\right.$, Fig. 8), Letter symbols indicate the different treatments. Vertical error bars represent the range obtained when $\Delta \mathrm{CO}_{2}$ is estimated from $\Delta \mathrm{O}_{2}$ using RQs of 1.1 and 1.3. Horizontal error bars represent the range obtained when $R_{C} / R_{N}$ values for faunated sediment are estimated using transport coefficient ratios $\left(\mathrm{D}_{\mathrm{C}} / \mathrm{D}_{N}\right)$ of 0.6 to 1.0. The 1:1 line is shown for comparison

for 60 to $80 \%$ of the measured DIN efflux; proportionally highest in the control and lowest in the Nereis diversicolor treatments. A much wider range is apparent in the systems devoid of algae, ranging from $30 \%$ in the control to $100 \%$ of the DIN efflux in the $N$. virens treatments. Although the present data provide no quantitative differentiation between the various nitrogen sinks, it is generally accepted that denitrification is the most important scavenger of combined inorganic nitrogen in marine sediments (Seitzinger 1988).

\section{Ecological implications}

Based on fluxes and transformations determined in this study, the potential impact of Nereis diversicolor and $N$. virens for sedimentary carbon and nitrogen dynamics in shallow coastal sediments can be evaluated in the presence and absence of phytoplankton in the overlying water (Table 4). It should be noted, however, that the present laboratory experiment does not include other autorhthnnnus (i o henthir mirroaldgae) and allochthonous (i.e. drifting seaweeds) sources of organic matter. Ingestion by animals and incorporation into sediments of these organic sources under natural conditions may affect fluxes and transformations of carbon and nitrogen compared with the laboratorybased budgets presented here. 
Most of the organic carbon and nitrogen captured by suspension-feeding Nereis diversicolor are lost as excess flux to the water column via metabolic processes by bacteria and the worms themselves, but about $30 \%$ are retained within the sediment (Table 4 ) About $2 / 3$ of the retained carbon and nitrogen is incorporated into living tissue by the growing worms. The remainder is either assimilated into microbial biomass lost as $\mathrm{N}_{2}$ via denitrification, or stored as undecomposed algal remains within the sediment. It appears therefore that organic carbon and nitrogen accumulates in sediments inhabited by $N$. diversicolor during periods of high phytoplankton availability (e.g. spring and fall bloom periods). A net loss of sedimentary carbon and nitrogen always occurs in the presence of $N$. virens irrespective of phytoplankton concentration in the overlying water (and for $N$. diversicolor without algae, Table 4 ). Both animals and bacteria enhance the overall benthic metabolism despite the lack of any organic input. Most of the excess carbon loss is due to microbial mineralization processes, whereas $\mathrm{NH}_{4}{ }^{+}$excretion by animals appears to be more important for nitrogen. Accordingly, populations of suspension-feeding $N$. diversicolor are potential net increasers of sedimentary organic matter during periods with sufficient phytoplankton in the overlying water, but net decreasers when no phytoplankton is present. Populations of $N$. virens, on the other hand, are always net decreasers of organic matter in sediments.

Surface deposit-feeding polychaetes, like nereids, may have territorial struggles resulting in disturbances of the feeding activity or increased emigration (Evans 1973). In some cases it may lead to complete spatial separation of populations of different species (Miron \& Kristensen 1993). The ability to change feeding mode may, however, reduce competitive interactions (Levin 1982, Taghon 1992). Thus, Nereis diversicolor spends less time at the surface when suspension feeding, which reduces the chance of confrontation with neighboring individuals. The adaptation of $N$. diversicolor to parttime suspension feeding creates a competitive release and allows species like $N$. diversicolor and $N$. virens to coexist. The enrichment of surface sediments with labile organic matter caused by suspension-feeding $N$. diversicolor, which is a nutritious food source for deposit feeders like $N$. virens, may contribute further to reducing competition and promoting coexistence. Nevertheless, these 2 co-occurring and congeneric polychaete species have very different impacts on sediment biogeochemistry due to their different feeding behaviour. This fact must be considered when the role of these and other related infaunal species on sediment processes are evaluated, i.e. the feeding biology and behaviour of infaunal organisms are important for their influence on element cycling in coastal marine environments.
Table 4. Budgets of carbon and nitrogen fluxes ( $\mathrm{mmol} \mathrm{m} \mathrm{m}^{-2} \mathrm{~d}^{-1}$ ) in sediments inhabited by Nereis diversicolor (AD, D) and $N$. virens $(\mathrm{AV}, \mathrm{V}$ ) in the presence and absence of phytoplankton in the water column. Values are given as the difference between systems with and without nereids and are averaged from Day 7 onwards $(20 \mathrm{~d})$. The $\mathrm{CO}_{2}$ efflux is estimated from measured $\mathrm{O}_{2}$ uptake by applying a mean $R Q$ of 1.2 for both sediment fluxes and worm respiration. Microbial respiration (resp.) and mineralization (min.) are estimated as the difference between total rates and worm contribution. Growth of nereids is transformed into carbon and nitrogen units using appropriate conversion factors (Vedel \& Riisgård 1993, Nielsen et al. 1995). Positive values indicate input to, and negative values indicate loss from, the sediment system

\begin{tabular}{|lcccc|}
\hline & AD-AC & D-C & AV-AC & V-C \\
\hline POC captured & 139.4 & 0 & -0.4 & 0 \\
CO ${ }_{2}$ efflux & & & & \\
$\quad$ Worm resp. & -40.6 & -9.1 & -5.3 & -6.6 \\
$\quad$ Microbial resp. & -60.6 & -13.7 & -18.5 & -11.4 \\
C-retained & & & & \\
$\quad$ Worm growth & 26.5 & -2.8 & 1.2 & -3.7 \\
$\quad$ Sediment & 11.7 & -20.0 & -25.4 & -21.7 \\
PON captured & 25.4 & 0 & -0.1 & 0 \\
DIN efflux & & & & \\
$\quad$ Worm excr. & -4.4 & -1.1 & -1.6 & -2.0 \\
$\quad$ Microbial min. & -13.1 & -1.4 & -0.6 & 1.4 \\
N-retained & & & & \\
$\quad$ Worm growth & 5.1 & -0.6 & 0.3 & -0.7 \\
$\quad$ Sediment & 2.8 & -1.9 & -2.6 & 0.1 \\
& & & & \\
\hline
\end{tabular}

Acknowledgements. This study was supported by the Danish Environmental Research Program from 1992 to 1996, Centre for Strategic Environmental Research in Marine Areas and SNF (grant no. 9601423).

\section{LITERATURE CITED}

Aller RC (1982) The effects of macrobenthos on chemical properties of marine sediment and overlying water. In: McCall PL, Tevesz MJS (eds) Animal-sediment relations. Plenum Press, New York, p 53-102

Aller RC (1994) Bioturbation and remineralization of sedimentary organic matter: effects of redox oscillation. Chem Geol 114:331-345

Aller RC, Aller JY (1992) Meiofauna and solute transport in marine muds. Limnol Oceanogr 37:1018-1033

Aller RC, Aller JY (1998) The effect of biogenic irrigation intensity and solute exchange on diagenetic reaction rates in marine sediments. J Mar Res 56:905-936

Aller RC, Mackin JE (1989) Open-incubation, diffusion methods for measuring solute reaction rates in sediments. J Mar Res 47:411-440

Aller RC, Yingst JY (1985) Effects of the marine deposit-feeders Heteromastus filiformis (Polychaeta), Macoma balthica (Bivalvia), and Tellina texana (Bivalvia) on averaged sedimentary solute transport, reaction rates, and microbial distributions. J Mar Res 43:615-645

Andersen $F \varnothing$, Kristensen $E$ (1988) The influence of macrofauna on estuarine benthic community metabolism: a microcosm study. Mar Biol 99:591-603 
Andersen Fø, Kristensen E (1991) Effects of burrowing macrofauna on organic matter decomposition in coastal marine sediments. Symp Zool Soc Lond 63:69-88

Armstrong FAJ, Stearns CR, Strickland JDH (1967) The measurement of upwelling and subsequent biological processes by means of the Technicon Autoanalyzer and associated equipment. Deep-Sea Res 14:381-389

Bender K, Davis WR (1984) The effect of feeding by Yoldia limatula on bioturbation. Ophelia 23:91-100

Berner RA (1977) Stoichiometric models for nutrient regeneration in anoxic sediments. Limnol Oceanogr 22:781-786

Bemer RA (1980) Early diagenesis, a theoretical approach. Princeton University Press, Prunceton, NJ

Blackburn TH (1988) Benthic mineralization and bacterial production. In: Blackburn TH, Sorensen $J$ (eds) Nitrogen cycling in coastal marine environments. John Wiley and Sons, London, p 175-190

Bower CE. Holm-Hansen $T$ (1980) A salicylate-hypochlorite method for determining ammonia in seawater. Can J Fish Aquat Sci 37:794-798

Cammen LM (1987) Polychaeta. In: Pandian TJ, Vernberg FJ (eds) Animal energetics. Academic Press, New York, p 217-260

Eckman JE, Nowell ARM, Jumars PA (1981) Sediment destabilization by animal tubes. J Mar Res 39:361-374

Emerson S, Jahnke R, Heggie D (1984) Sediment-water exchange in shallow water estuarine sediments. J Mar Res 42:709-730

Evans SM (1973) A study of fighting reactions in some nereid polychaetes. Anm Behav 21:138-146

Fenchel $T$ (1996) Worm burrows and oxic microniches in marine sediments. 1. Spatial and temporal scales. Mar Biol $127: 289-295$

Gerritsen J. Holland AF, Irvine DE (1994) Suspension-feeding bivalves and the fate of primary production: an estuarine model applied to Chesapeake Bay. Estuaries 17: $403-416$

Goerke H (1971) Die Ernährunsweise der Nereis-Arten (Polychaeta, Nereidae) der Deutschen Küsten. Veröff Inst Meeresforsch Bremerh 13:1-50

Graf G, Rosenberg R (1997) Bioresuspension and biodeposktion: a review. J Mar Syst 11:269-278

Hall POJ, Aller RC (1992) Rapid, small-volume, flow injection analysis for $\mathrm{TCO}_{2}$ and $\mathrm{NH}_{4}$ in marine and freshwaters. Limnol Oceanogr 37:1113-1119

Hansen LS, Blackburn TH (1992) Mineralızation budgets in sediment microcosms: effect of the infauna and anoxic conditions. FEMS Microbiol Ecol 102:33-43

Hansen K, Kristensen E (1997) Impact of macrofaunal recolonization on benthic metabolism and nutrient fluxes in a shallow marine sediment previously overgrown with macroalgal mats. Estuar Coast Shelf Sci 45:613-628

Huettel M (1990) Influence of the Lugworm Arenicola marina on porewater nutrient profiles of sand flat sediments. Mar Ecol Prog Ser 62:241-248

Joye SB, Smith SV, Hollibaugh JT, Paerl HW (1996) Estimating denitrification rates in estuarine sediments: a comparison of stoichiometric and acetylene based methods. Biogeochemistry 33:197-215

Klump JV, Martens CS (1987) Biogeochemical cycling in an organic-rich coastal marine basin. 5. Sedimentary nitrogen and phosphorus budgets based upon kinetic models, mass balances, and the stoichiometry of nutrient regeneration. Geachim Cosmochim Acta 51:1161-1173

Krager CD, Woodin SA (1993) Spatial persistence and sediment disturbance of an arenicolid polychaete. Limnol Oceanogr 38:509-520
Kristensen E (1988) Benthic fauna and biogeochemical processes in marine sediments: microbial activities and fluxes. In: Blackburn $\mathrm{TH}$, Sorensen J leds) Nitrogen cycling in coastal marine environments. John Wiley and Sons, London, p 275-299

Kristensen E (1989) Oxygen and carbon dioxide exchange in the polychaete Nereis virens: influence of ventilation activity and starvation. Mar Biol 101:381-388

Kristensen E (1993) Seasonal variations in benthic community metabolism and nitrogen dynamics in a shallow, organic poor Danish lagoon. Estuar Coast Shelf Sci 37:565-586

Kristensen E, Andersen FO (1987) Determination of organic carbon in marine sediments: a comparison of two CHNanalyzer methods. J Exp Mar Biol Ecol 109:15-23

Kristensen E, Blackburn TH (1987) The fate of organic carbon and nitrogen in experimental marine sediment systems: influence of bioturbation and anoxia. J Mar Res 45:231-257

Kristensen E, Hansen K (1995) Decay of plant detritus in organic-poor marine sediment: production rates and stoichiometry of dissolved $\mathrm{C}$ and $\mathrm{N}$ compounds. I Mar Res 53: $675-702$

Kristensen E, Hansen K (1999) Transport of carbon dioxide and ammonium in bioturbated (Nereis diversicolor) coastal, marine sediments. Biogeochemistry 45:147-168

Kristensen E, Andersen FØ, Blackburn TH (1992) Effects of benthic macrofauna and temperature on degradation of macroalgal detritus: the fate of organic carbon. Limnol Oceanogr 37:1404-1419

Levin LA (1982) Interference interactions among tube dwelling polychaetes in a dense infaunal assemblage. J Exp Mar Biol Ecol 65:107-119

Marinelli RL (1994) Effects of burrow ventilation on activities of a terebellid polychaete and silicate removal from sedrment pore waters. Limnol Oceanogr 39:303-317

Marinelli RL, Boudreau BP (1996) An experimental and modeling study of $\mathrm{pH}$ and related solutes in an irrigated anoxic coastal sediment. J Mar Res 54:939-966

Martin WR, Banta GT (1992) The measurement of sediment irrigation rates: a comparison of the $\mathrm{Br}^{-}$tracer and ${ }^{222} \mathrm{Rn} /{ }^{22 t} \mathrm{Ra}$ disequilibrium techniques. J Mar Res 50: $125-154$

Meadows PS, Tait J, Hussain SA (1990) Effects of estuarine infauna on sediment stability and particle sedimentation Hydrobiologia 190:263-266

Miller J)C, Bock MJ, Turner EJ (1992) Deposit and suspension feeding in oscillatory flows and sedıment fluxes. J Mar Res 50:489-520

Miron G, Kristensen E (1993) Factors influencıng the dıstribution of nereid polychaetes: the sulfide aspect. Mar Ecol Prog Ser 93:143-153

Nielsen AM, Eriksen NT, Iversen JJL, Riisgard HU (1995) Feeding, growth and respiration in the polychaetes Nereis diversicolor (facultative filter-feeder) and $N$. varens Iomnivorous) - a comparative study. Mar Ecol Prog Ser $125: 149-158$

O'Malley KL, Terwilliger RC (1975) Aspects of nitrogen metabolism in the terebellid polychaete Pista pacifica Berkeley. Comp Biochem Physiol 52(A):367-369

Parsons TR, Maita Y, Lalli CM (1984) A manual of chemical and biologicai methods for seawater andiysis. Fenyanuen Press, Oxford, p 173

Regnault M 11981) Respiration and ammonia excretion of the shrimp Crangon crangon L.: metabolic response to prolonged starvation. 3 Comp Physiol 141:549-555

Reichardt W (1988) Impact of bioturbation by Arenicola marina on microbiological parameters in intertidal sediments. Mar Ecol Prog Ser 44:149-158 
Rhoads DC, McCall PL, Yingst JY (1978) Disturbance and production on the estuarine seafloor. Am Sci 66:577-586

Riisgărd HU (1991) Suspension feeding in the polychaete Nereis diversicolor. Mar Ecol Prog Ser 70:29-37

Riisgård HU, Larsen PS (1995) Filter-feeding in marine macro-invertebrates: pump characteristics, modelling and energy cost. Biol Rev 70:67-106

Riisgård HU, Christensen PB, Olesen NJ, Petersen JK, Møller MM, Andersen P (1995) Biological structure in a shallow cove (Kertinge Nor, Denmark) - control by benthic nutrient fluxes and suspension-feeding ascidians and jellyfish. Ophelia 41:329-344

Riisgård HU, Poulsen L, Larsen PS (1996) Phytoplankton reduction in near-bottom water caused by filter-feeding Nereis diversicolor-implications for worm growth and population grazing impact. Mar Ecol Prog Ser 141: $47-54$

Rowden AA, Jones MB (1994) A contribution to the biology of the burrowing mud shrimp, Callianassa subterranea (Decapoda: Thalassinidea). J Mar Biol Assoc UK 74: 623-635

Seitzinger SP (1988) Denitrification in freshwater and coastal marine ecosystems: ecological and geochemical significance. Limnol Oceanogr 33:702-724

Taghon GL (1992) Effects of animal density and supply of deposited and suspended food particles on feeding, growth and small-scale distributions of two spionid polychaetes. J Exp Mar Biol Ecol 162:77-95

Editorial responsibility: Tom Fenchel (Contributing Editor), Helsingor, Denmark van Duyl FC, Kop AJ, Kok A, Sandee AJJ (1992) The impact of organic matter and macrozoobenthos on bacterial and oxygen variables in marine sediment boxcosms. Neth J Sea Res 29:343-355

Vedel A (1998) Phytoplankton depletion in the benthic boundary layer caused by suspension-feeding Nereis diversicolor (Polychaeta): grazing impact and effect of temperature. Mar Ecol. Prog Ser 163:125-132

Vedel A, Riisgård HU (1993) Filter-feeding in the polychaete Nereis diversicolor: growth and bioenergetics. Mar Ecol Prog Ser 100:145-152

Vedel A, Andersen BB, Riisgard HU (1994) Field investigations of pumping activity of the facultatively filter-feeding polychaete Nereis diversicolor using an improved infrared phototransducer system. Mar Ecol Prog Ser 103 $91-101$

Webster IT (1992) Wave enhancement of solute exchange within empty burrows. Limnol Oceanogr 37:630-644

Westrich JT, Berner RA (1984) The role of sedimentary organic matter in bacterial sulfate reduction: the $\mathrm{G}$ model tested. Limnol Oceanogr 29:236-249

Wheatcroft RA, Olmez I, Pink FX (1994) Particle bioturbation in Massachusetts Bay: preliminary results using a new deliberate tracer technique. J Mar Res 52:1129-1150

Yager PL, Nowell ARM, Jumars PA (1993) Enhanced deposition to pits: a local food source for benthos. J Mar Res 51. $209-236$

Submitted: November 15, 1998, Accepted: June 21, 1999 Proofs received from author(s): January 12, 2000 